\title{
RESEARCH OF THE ECOLOGICAL ENVIRONMENT IN SHANGHAI WORLD EXPO PARK
}

\author{
Yangluxi LI \\ School of Architecture, Syracuse University, NY, USA \\ Received 06 March 2017; accepted 23 November 2017
}

\begin{abstract}
The conceiving of future cities converged at the 2010 Shanghai World Expo from 246 different countries and regional organizations. With a focus on the world energy crisis, the expo's design, construction and exhibitions offer solutions to this issue. Energy planning is integrated into the overall planning of the expo to continue and diffuse the follow-up effect of the Shanghai World Expo in the social, economic, environmental aspects. In order to obtain a deeper understanding of the urban "heat-island effect" distribution causes and a series of climatic factors closely related to urban heat environment. In this paper, we combine the Ecotect software and CFD software, simulating the thermal environment of the city in the Shanghai World Expo. With broad application, these research methods can also be introduced in future urban planning, formulate design guidelines for corresponding urban climate environments according to different geographical and climatic characteristics of cities. We extract the application and exhibition of a future city's construction and technology from the World Expo venues. The statistical analysis provides information on the construction trends of future cities.
\end{abstract}

Keywords: urban heat-island effect, ecological environment, digital technology, urban planning, Shanghai World Expo.

\section{Introduction}

The public space design of Shanghai World Expo 2010 is comprehensive and a little bit complex, the physical plan and spatial pattern are different from the usual urban open space. To achieve this goal, first of all, principal contradiction need to be straightened. The principal contradiction is that under condition of limited time and space, a large number of facilities need to be put in place, and people flow need to be reasonably and efficiently organized, the people's visiting habit need to be changed from passive waiting in open space to active "waiting", "visiting", "touring" and "interacting". Based on this analysis, some methods are used, including experience data, data model, and on-site feedback, the research issues are explored deeply by leveled and branched, including the macro, meso and micro level. The macro-level overall strategies include overall layout and design strategies, the mesolevel itemized design strategies, the subsystem includes square system, green space system and lighting system. The micro-level user-friendly facilities design strategies and micro-Operations Management, the user-friendly facilities include sun-shading system, mist spraying system, benches facilities system, drinking water facilities system and other related facilities.
More than 200 countries and organizations participated in the 2010 Shanghai World Expo. The number of visitors reached as high as 70 million people. The World Expo can date back to the merchants' assembly from the Middle Ages. Currently, the World Expo is not only used for business exchanges, communication in technology, culture and nationality, but is also a stage to showcase and understand the world. The World Expo is a staple of social civilization, wisdom and visions of the future.

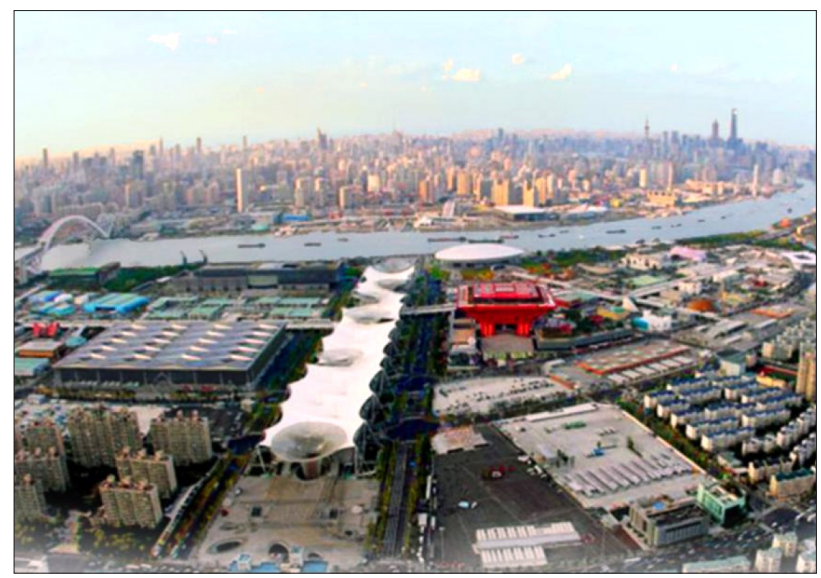

Figure 1. Aerial view of Expo Park in Shanghai

${ }^{*}$ Corresponding author. E-mail: $y l i 220 @ s y r . e d u$ 
Shanghai World Expo is located in both sides of Huangpu River, its area has reached 5.4 square kilometres (Figure 1). The expo consists of five complexes, respectively, the Independent complex, the Joint complex, the Enterprises complex, the Theme complex and the China complex. The Independent complex has been concentrated around the Huangpu River, each building of which is funded by one state independently, showing the scientific and technological achievements of China. Part of the Joint Pavilion buildings are jointly built by multiple countries. The others are financed by China and leased to participating countries. The Enterprises buildings are accessible to international exhibitors (Li 2012).

The Expo's theme is an important part of the World Expo which always was chosen from different perspectives. "Better City, Better Life" is the theme for the 2010 Shanghai World Expo. From 2003 to 2009, the BIE and the Shanghai municipal government hold a global forum on the theme 'Better City, Better Life' every year. The theme of Expo 2010 represents people's longing for the future urban living life and the close attention of international organizations to future policies about the urban and sustainable development. The number of population lived in cities around the world is only $2 \%$ in 1800 . And to the 1950 , $29 \%$ of the people had moved into the cities. In 2000, the $50 \%$ population of the world went to the cities. The United Nations predicts that the city's population will account for $55 \%$ of the world's population by 2010 . Despite the rapid development of cities, there is no doubt that high-density living patterns still cause many problems for cities today such as spatial conflicts, cultural conflicts, resource shortage and environmental deterioration. If there is no effective methods to control the scale of cities, unlimited urban sprawl will exacerbate these problems and reduce people's quality of urban life in cities. These issues affect many aspects of social life, such as the arts in designing education, international relations and trade, and tourism. Facing such discord, Expo 2010 Shanghai China roposes the concept of a "City of Harmony" responding to the appeal

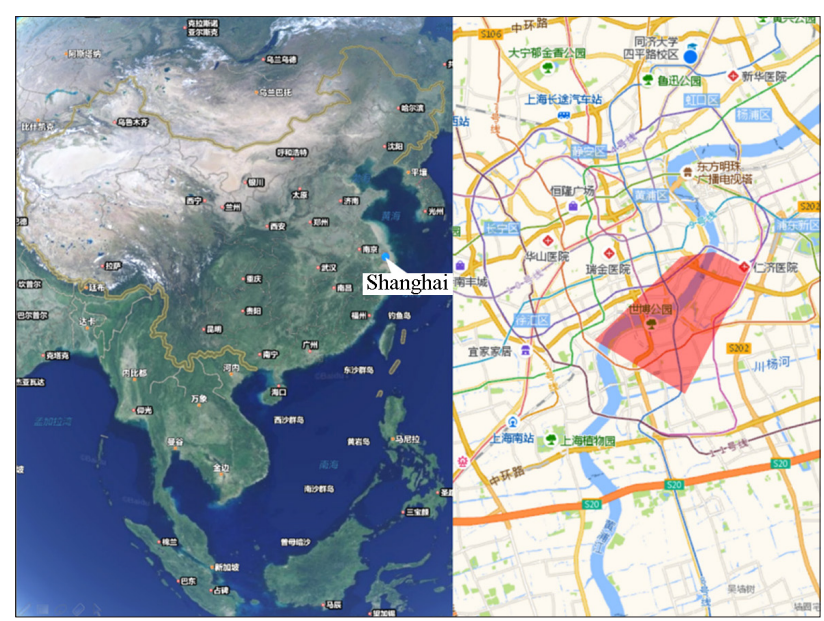

for "Better City, Better Life". The City of Harmony features harmonious co-existence of diverse cultures, harmonious economic development, harmonious living in the age of science and technology, the cells of the city, harmonious functioning of communities, and harmonious interactions between urban and rural areas.

Combining the strategies requirements of urban development in Shanghai area on the World Expo, and based on the unique characteristics of humanities content, location and resources advantages, Expo region development makes full use of the foreign central activities zone (CAZ) trends of functional integration. The central activities district in the central business district (CBD) with strictly business-oriented functions, extended to become an urban mixed-use area with commercial, business, cultural tourism, restaurants and residential programming. It is essential for the business district in the city center to shift towards a more integrated function (Li 2016). The central activities area focuses on public gathering spaces, including large recreational and cultural facilities like an urban leisure square, museums and galleries. These spaces are combined with diversified cultural facilities such as cinemas, theatres, cafes and bars. The central activities area puts emphasis on functional composite use, including land for commercial, business and facilities of compatible cultures, leisure, and entertainment. It also highlights the principles of sustainability to enhance the efficiency of the area and its facilities. It lays stress on human activities, energy use reduction and spatial nature to create a " 24 -hour activity center and vitality center". This reduces the phenomenon of a "boiling city" during the day and an "empty city" in the evening in the central business district. More attention is put on the diversity of the crowd. As a result of cultural, residential, tourist and other functions, local people and foreigners join together to make a diverse population (Hao et al. 2011). According to the overall development of Shanghai city and the Huangpu River, the Expo and surrounding areas, including the Expo Area, Yaohua Area and Sanlin Area, Xuhui Area, and Binjiang area, will become a large comprehensive city of public activity in the future. The World Expo area will give full attention to its unique resources, to promote the construction of Shanghai into an international metropolis. Its goal is to lead the future through innovation and transformation, highlighting international cultural function by focusing on the development of creative cultural exhibitions, business headquarters, high-end exhibitions, tourism and leisure and ecological construction to become an iconic, municipal public activity center. The expo and the surrounding area fuse multiple functions, unique spaces, pleasant environments and convenient transportation to embody low carbon and innovation. It will prove to be a new landmark in the world, full of vitality and attraction.

Figure 2. Location diagram 


\section{General regulations}

\subsection{Exhibition and business as the core, mixed functions layout, three-dimensional development}

The attractiveness of an urban center first and foremost lies in its diversity. The basic goal is to meet the demand for official businesses, create more opportunities for people to live and enjoy leisure downtown and allow the area to remain vibrant after working hours (Tan et al. 2010). On functionality, conventions for large-scale international conferences and forums, mainly high-end boutique specializing in the exhibition and business-oriented headquarters, provides hotels, apartments and other flexible living models. Adequate commercial retail, cultural and recreational facilities all provide a variety of functions and activities in support of each other. Abandoning the traditional layout model, conferences and exhibitions follow the principle of integration and mixed-land use, emphasizing the mixed function of plane and solid. On scale composition, commercial, residential, and other ancillary features take up more than $30-40 \%$ of the entire exhibition business district (Bohnenstengel et al. 2011).

\subsection{Creation of scale suitable street space and life}

Using small neighborhoods, high density, compact architectural spaces, paying attention to the humanistic space of integral design, emphasizing the street interface continuity, providing ample urban texture and multiple activities space, such as the unified overall layout, regional well-defined architecture layout models (Tomlinson et al. 2011). Buildings cling to the street boundaries, forming suitable courtyards, internal passageways, squares and complete streets. High-rise buildings can be arranged in the middle of or behind a city block, allowing the building height to increase from the street and break up large volumes into smaller individual combinations to guarantee land development and improve human scale. Functions of public activities on both sides of the ground floor encourages business, cultural entertainment, as well as the entrance hall (Lamberti et al. 2011). The transparent underlying interface is recommended to improve street dynamics, excite the street level atmosphere and ensure the spacial qualities between buildings. This includes building height, horizontal building lines, ground floor facade organization, building materials, user activities and store design coordination.

\subsection{Establishment of three-dimensional public activities system and humanistic pedestrian environment}

During the World Expo events, a network of public spaces was formed by green space along the river, the northsouth axis and the wedge-shaped green belt from the river towards the hinterland. The planning to follow will focus on developing ground level and underground connections to create a balance of indoor and outdoor space (Yang et al. 2014). It will make full use of green space, public channels, squares, underground streets, airways and important public buildings to build a continuous and ample public activities system. It is essential to constitute variety and hierarchical public space systems, combined with a functional layout and public activities. It should be in accordance with hierarchical and grading layout principles to set the appropriate scaling and dimension of green spaces, squares and pedestrian space according to local conditions. It is obligatory to strengthen the pedestrian system with continuity and establish a direct relationship between the major facilities and public spaces, while reducing unnecessary upper and lower transportation and abating ground traffic density. It is important to emphasize the three-dimensional organization of public space by coordinating public areas at ground, elevated and underground levels (Yang 2016). This includes pedestrian routes (including business streets), walkways, overpasses, underground routes (including underground shopping malls and subway stations), city squares (including sunken plazas, roof plazas) and the major buildings' interior space. It is imperative to encourage public space and architectural space to intertwine with each other, bringing public areas deep inside buildings. Blurring the boundaries of public spaces and buildings can turn important public buildings into nodes that are interconnected w.58ith the flow of traffic (Callahan 2012).

\subsection{Continuation of world expo park space system, highlighting the iconic status of the Chinese hall}

The World Expo area, relying on the unique natural and cultural landscape, constructs activities and visual corridors to link the Chinese Pavilion and Expo Cultural Center. It creates an iconic expo logo through its zones, nodes, landmarks, channels and so on. Through the "Green Valley" design technique, the expo highlights the iconic status of its Chinese Pavilion, forming a unique central water city landscape (Zhang 2013).

\subsection{Extension of the Expo ecological philosophy, promote low carbon environmental protection technologies}

The philosophy is to inherit and continue the sustainable development concept of the expo city. It will take full advantage of the existing energy-saving facilities, promote low-carbon transportation, and popularize green buildings with clean energy, energy-saving and sustainable technologies (Xu et al. 2010). The expo will provide riverside trolleys, public transportation and walking systems, promote passive energy-saving buildings of low height and large depth and improve energy use conditions by "natural" means such as natural ventilation and lighting. It will also create "micro-climates" through the "eco-Green Valley" design techniques combined with a green platform of gardens and roof gardens (Oleson et al. 2011). Additionally, it has a plan distributed energy supply system, 
garbage pneumatic conveying system, potable water treatment and rainwater collection systems and integrated solar, geo-thermal and river heat pumps and other new sources of energy.

In this paper we will take the Shanghai Expo Park as the research object. The simulation model of the digital technology on the free trade area in the summer thermal environment will be used in order to provide some references for the future city planning and space development layout of Shanghai city (Basara et al. 2010). The research tools involved are Air-pak software and Ecotect software.

\section{Analysis of meteorological conditions in Shanghai City}

To perform simulation experiments on Shanghai Expo Park, we must first study the typical climate condition of Shanghai city in summer, and take it as the initial simulation condition. Shanghai is located in north latitude 31

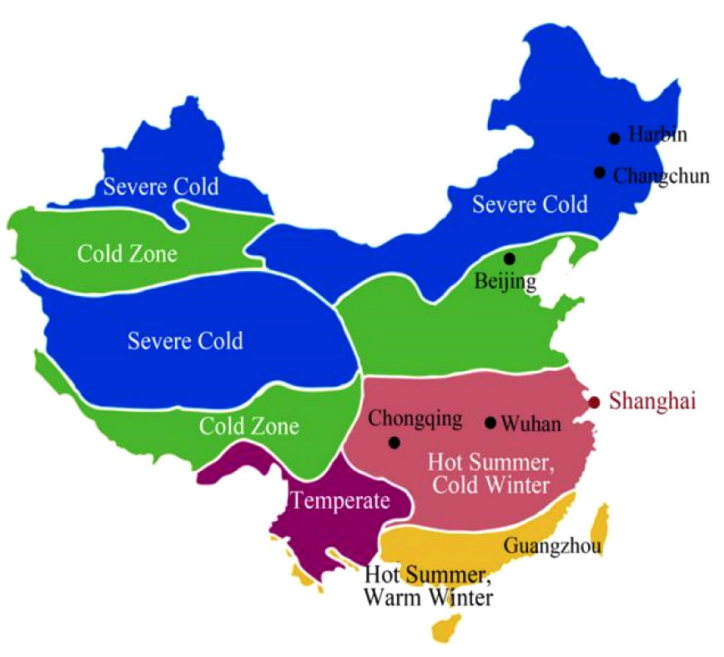

Figure 3. China building climate zoning map degrees 14 minutes, east longitude 121 degrees, 29 minutes, at the forefront of the Yangtze River Delta near east China Sea (Figure 2). According to the Chinese architectural climatic zoning map (Figure 3), Shanghai belongs to the climate District III - the hot summer and cold winter zone. The climate of this zone is characterized by the high summer temperature and high humidity (Emmanuel, Krüger 2012). The air humidity is so high that sweat of the human body is difficult to discharge the heat dissipation. This is an important factor leading to the summer heat discomfort within the city. According to the analysis from Ecotect software of Shanghai's annual temperature, solar radiation, thermal comfort distribution map (Figure 4) and the Shanghai annual temperature distribution map (Table 1), we can arrive at a conclusion. This is that the most direct solar radiation value is in May, the highest temperature is in June and the average maximum temperature is in July, while the average maximum temperature is 28 degrees during the year. Accordingly, we chose the highest average temperatures in July as the simulation time. Figure 5 is the direction, frequency and speed of the wind distribution map of Shanghai in July at noon (10:00-14:00) (Steeneveld et al. 2011). It can be concluded from the figure that south, southeast, southwest winds mainly appear in the afternoon in July. The wind speed can be as high as $50 \mathrm{~km} / \mathrm{h}$, and the average wind speed is $15 \mathrm{~km} / \mathrm{h}$. According to statistical results of Ecotect, for the convenience of analog computation, we will set the incident direction as southeast wind, wind speed as $15 \mathrm{~km} / \mathrm{h}$ and temperature as 28 degrees Celsius (Li et al. 2011).

\section{Establishment of CFD model}

After setting the initial conditions in the external environment, the complex park can be converted into digital models calculated in the CFD software. A city is complex with a massive collection of information. It will be a very

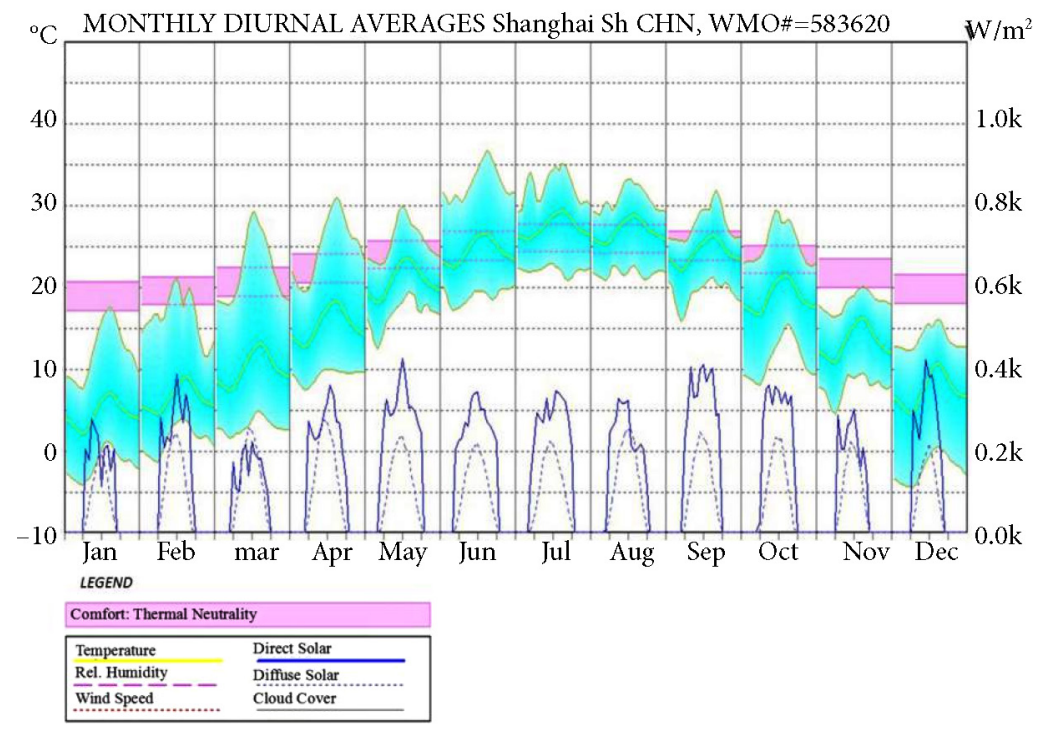

Figure 4. Annual temperature, solar radiation, thermal comfort distribution 
Table 1. Shanghai basic meteorologicaldate

\begin{tabular}{|c|c|c|c|c|c|c|c|c|c|c|c|c|c|}
\hline \multicolumn{14}{|c|}{ Shanghai basic meteorological data } \\
\hline Month & Jan. & Feb. & Mar. & Apr. & May. & Jun. & Jul. & Aug. & Sep. & Oct. & Nov. & Dec. & Annual \\
\hline Mean temperature $\left({ }^{\circ} \mathrm{C}\right)$ & 4.8 & 6.6 & 10 & 15.3 & 20.7 & 24.4 & 28.6 & 28.3 & 24.9 & 19.7 & 13.7 & 7.6 & 17.1 \\
\hline $\begin{array}{l}\text { Extreme maximum } \\
\text { temperature }\left({ }^{\circ} \mathrm{C}\right)\end{array}$ & 22.1 & 27 & 29.6 & 34.3 & 35.5 & 37.5 & 39 & 39.9 & 38.2 & 34 & 28.7 & 23.4 & 39.9 \\
\hline $\begin{array}{l}\text { Average maximum } \\
\text { temperature }\left({ }^{\circ} \mathrm{C}\right)\end{array}$ & 8.1 & 10.1 & 13.8 & 19.5 & 24.8 & 27.8 & 32.2 & 31.5 & 27.9 & 22.9 & 17.3 & 11.1 & 20.6 \\
\hline $\begin{array}{l}\text { Extreme minimum } \\
\text { temperature }\left({ }^{\circ} \mathrm{C}\right)\end{array}$ & -10.1 & -7.9 & -5.4 & -0.5 & 6.9 & 12.3 & 16.3 & 18.8 & 10.8 & 1.7 & -4.2 & -8.5 & -10.1 \\
\hline $\begin{array}{l}\text { Average mainmum } \\
\text { temperature }\left({ }^{\circ} \mathrm{C}\right)\end{array}$ & 2.1 & 3.7 & 6.9 & 11.9 & 17.3 & 21.7 & 25.8 & 25.8 & 22.4 & 16.8 & 10.6 & 4.7 & 14.1 \\
\hline Precipitation $(\mathrm{mm})$ & 74.4 & 59.1 & 93.8 & 74.2 & 84.5 & 181.8 & 145.7 & 213.7 & 87.1 & 55.6 & 52.3 & 43.9 & 1166.1 \\
\hline Relative humidity (\%) & 74 & 73 & 73 & 72 & 72 & 79 & 77 & 78 & 75 & 72 & 72 & 71 & 74 \\
\hline Precipitation days & 9.9 & 9.2 & 12.4 & 11.2 & 10.4 & 12.7 & 11.4 & 12.3 & 9.1 & 6.9 & 7.6 & 7.7 & 120.8 \\
\hline Sunshine hours & 114.3 & 119.9 & 128.5 & 148.5 & 169.8 & 130.9 & 190.8 & 185.7 & 167.5 & 161.4 & 131.1 & 127.4 & 1775.8 \\
\hline
\end{tabular}

Prevailing Winds Wind Frequency (Hrs) Location: Shanghai Sh CHN $\mathrm{WMO} \#=283620(31,4 ? 121.4 ?$ Date: 1 st July - 31 st July Time: $10.00-14.00$ Weather Tod
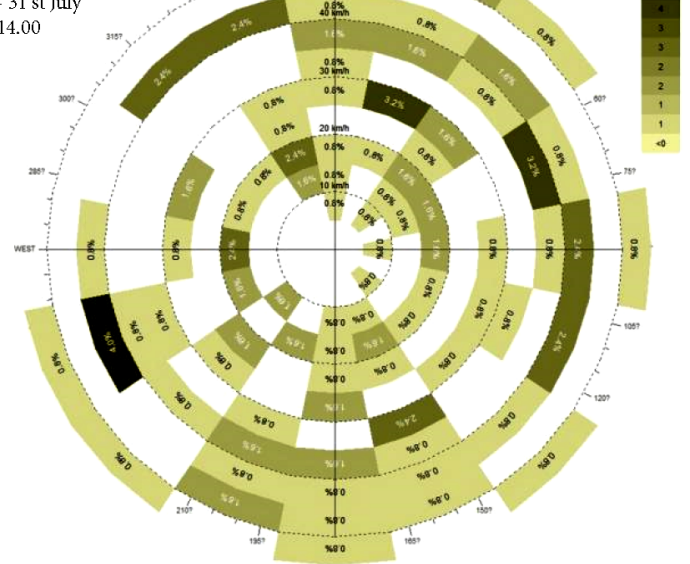

[Duration shown as percentages]

Figure 5. Shanghai July afternoon, the wind wind frequency, wind speed map arduous task to reflect all the information. Therefore, when establishing the CFD model of the park, we will use a focused model only considering the associated city thermal environment information, and taking different regions with the same attributes as a whole. According to the existing texture, the city will be simplified as boundaries on the conditions of main roads, plant trees and water. The city is divided into a plurality of areas (replaced by block), and each region will be endowed with the corresponding attributes according to the land use, building density, the volume rate and green rate. Figure 6 is an original appearance of land use map in Shanghai World Expo Park. Figure 7 is a land-planning map of Shanghai World Expo Park. Figure 8 is the subsequent development planning and land use map of Shanghai World Expo Park. Public space layout is "one major and four minor". "One major" refers to population concentrated land within the park (including China Pavilion, business and financial center). "Four minor" refers to the four sub park center distributed surrounding (including foreign pavilion, theme pavilion, the World Expo Center, arts center). These areas

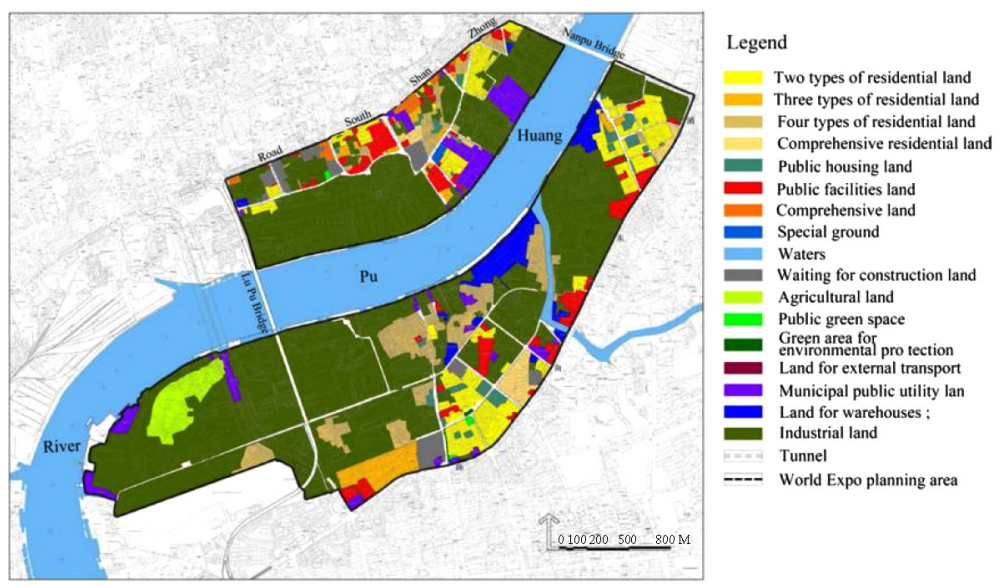

Figure 6. Land use map of Expo Park 

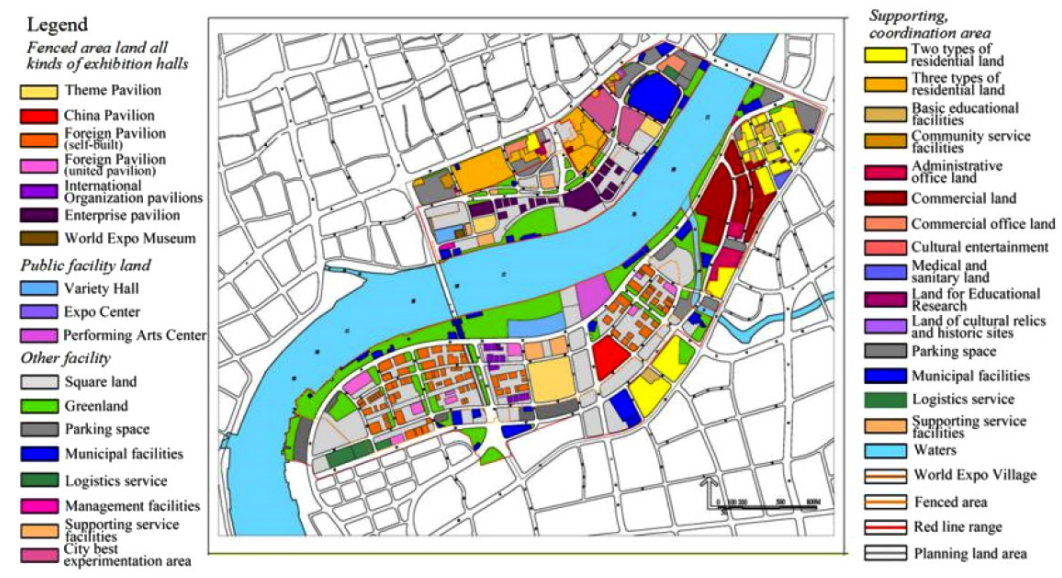

Figure 7. Land plan of Expo Park

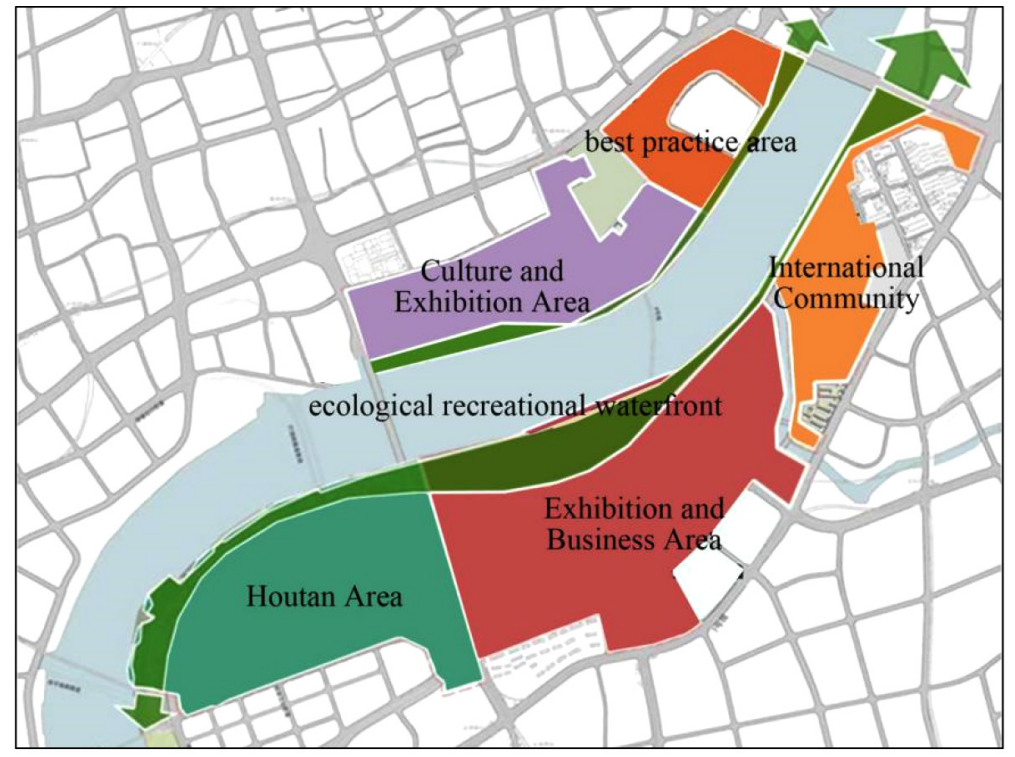

Figure 8. Future development plan of Expo Park

are characterized by high building density, large volume rate and dense visitor flowrate. The following establishment of CFD model will be determined according to the characteristics of the corresponding attribute (Scheuer et al. 2003).

When establishing the CFD model it should be according to the results of other research and, in general, the wind speed conditions and the effect of ventilation channel below $100 \mathrm{~m}$ is not obvious. It can achieve a considerably ideal effect of heat exhaust ventilation (Nichol, Wong 2005) only when the width of the ventilation channel reaches $150 \mathrm{~m}$ or more. Therefore, in terms of water, due to the narrow flow width of the Suzhou River and others, they are not taken into account when modeling. In terms of green space, more than $120 \times 120 \mathrm{~m}$ (the area is up to $1.44 \mathrm{ha}$ ) green space has the most significant ecological functions (Prakash et al. 2006) of reducing the land surface temperature. Therefore, when considering green space, we only take the relatively large area of parks and green space into account, eliminating small street greenbelt and gardens. According to boundaries distinguished by main roads, greenbelt, rivers, and various conditions, the city is divided into different regional plots (namely block in the model). Considering the different features that will (Stathopoulou, Cartalis 2007) probably appear in the simulation calculation process by digital model consisting of building density, volume rate, green rate and population density in different regions, the whole Expo Park can be divided into 5 grades (see Figure 8 ). This is followed by the first-degree region - China pavilion, four park deputy center (including commercial financial center, distributed activities land). Second-degree region - foreign pavilion, theme pavilion, enterprise pavilion and arts center. Third-degree region - low density commercial and residential areas. Fourth-degree region - city parks, large green space. Fifth-degree region - major river systems in the city (the Huangpu River, the Yangtze River). In the regional grading process, the basis of factors relevant to 
city heat environment are building density, volume percentage, green percentage, and population density. The average value of each parameter is used in this plot. Mainly the region block degree of accepting sun radiation is used, and the wind effect size is standard. Generally speaking, regions from first to fifth degree, the building density, volume rate and population density are reduced while green rate is incremental (see Figures 9-11). Due to the river (Huangpu River) acting as a ventilation corridor and effect of evaporation by water greater than grass, as well as the absorbing heat, the river system is in the fifth place. After finishing the determined grade, we need to divide model network grids. Generated network grid quality is effective in calculating

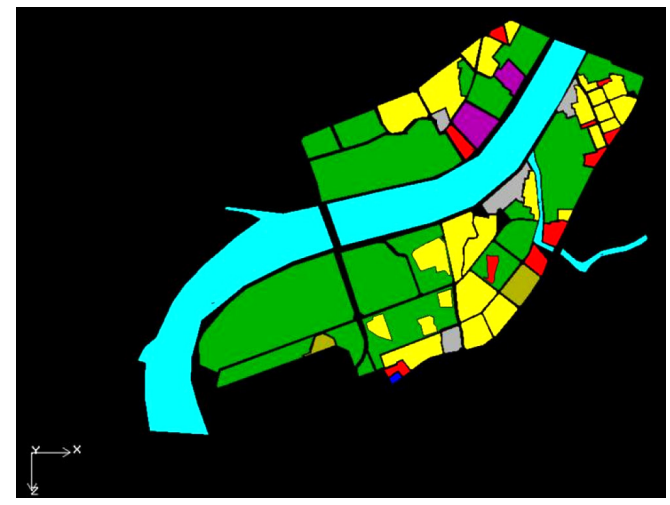

Figure 9. Regional classification of land use in CFD model (before the World Expo)

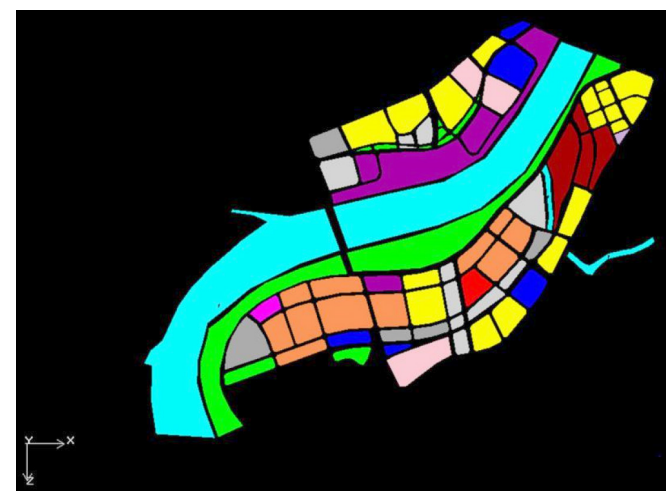

Figure 10. Regional classification of land use in CFD model (in the World Expo)

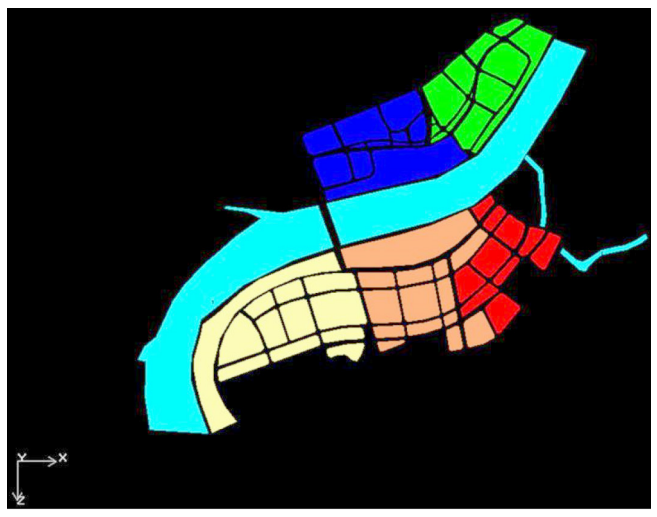

Figure 11. Regional classification of development plan in CFD model (After the World Expo) precision and stability. Generated strength of network grid is an important factor in measuring CFD general software performance. Our model implements a non-structure network grid technology to divide network grids. The divided network grid includes a variety of shapes, and works to express the surface shape of a complex city by improving mode simulation effect (see Figures 12-14). Non-structured grid is not affected by topology and boundary shape constraints of the solution domain. It is very convenient to construct and generate an adaptive mesh, automatically resizing the grid density based on flow field characteristics and improving the computational accuracy in the whole region effectively (Goward 2004).

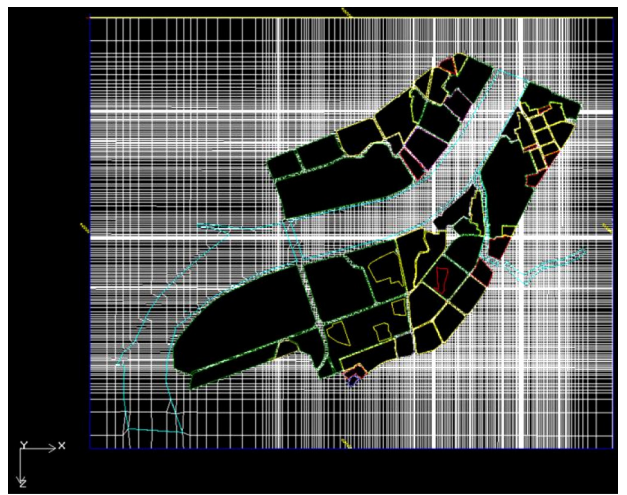

Figure 12. CFD digital model grid division (before the World Expo)

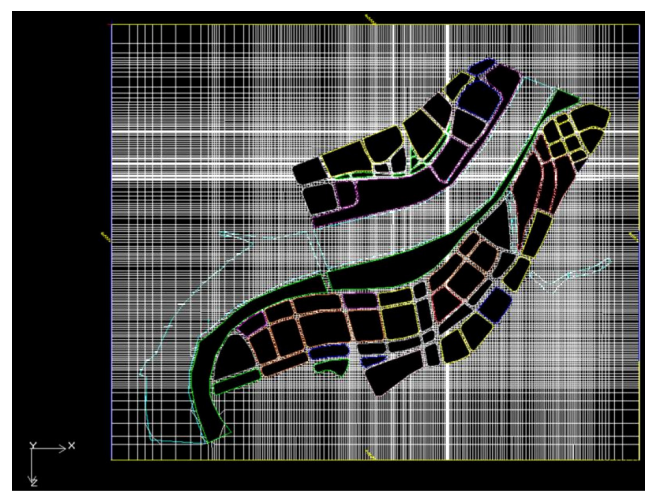

Figure 13. CFD digital model grid division (in the World Expo)

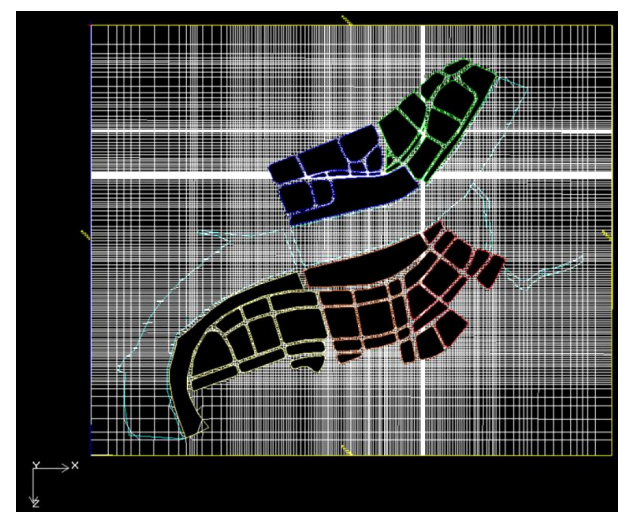

Figure 14. CFD digital model grid division (after the World Expo) 
The corresponding property is given to all levels of regions (block) according to the actual plot indicators, namely setting the model digital parameter is the most critical step in the simulation. For the urban areas at different levels, considering block models affected by the

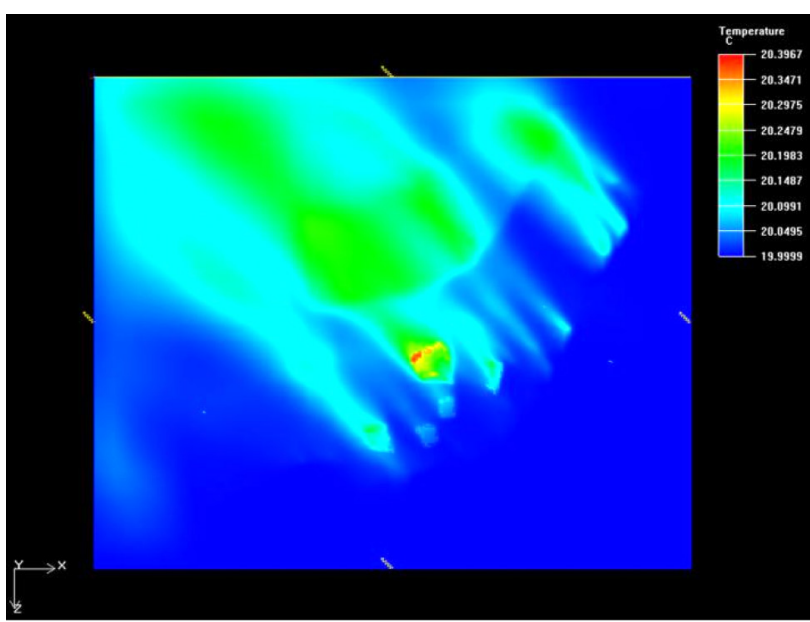

Figure 15. Temperature distribution over Expo Park (before the World Expo)

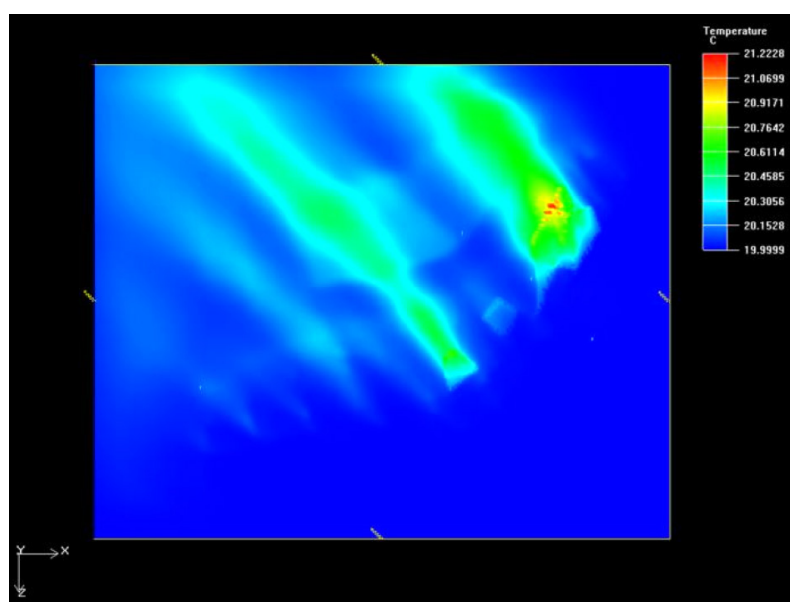

Figure 16. Temperature distribution over Expo Park (in the World Expo)

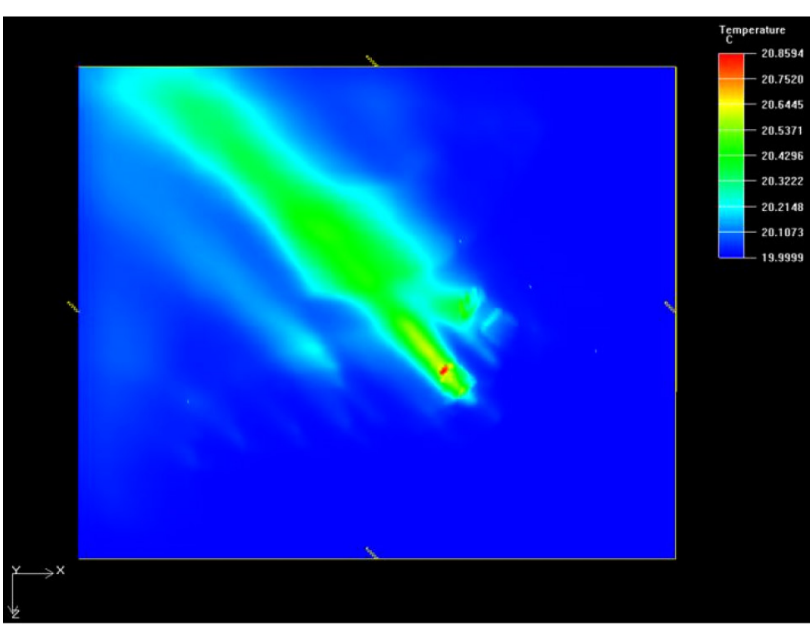

Figure 17. Temperature distribution over Expo Park (after the World Expo) degree of radiation from the sun and wind extent, it respectively transforms the building density, plot ratio, greening rate and population density into the property parameters (Yang 2014) of the block. For instance, the fivedegree region sets (the Huangpu River, the Yangtze River), zone properties (block type) into fluid (Fluid), fluid material (Fluid material) into water $\left(\mathrm{H}_{2} \mathrm{O}\right)$. This is because the block models are evaporating by solar radiation, and the top of the block needs to be set with upward ventilation inlets (opening) that have the same surface area. In accordance with the measured data, initial temperature of the wind is input at 25 degree Celsius. As the vegetation heat radiation capacity is obviously less than the building surface, heat capacity is relatively larger for the building surface. The latent heat storage capacity is greater than the sensitivity to heat. The four-degree region (green space) has a positive effect on improving city heat environment. The property of the block is set as hollow. According to measured quantity, initial temperature is set as 26 degrees Celsius. Second and third degree regions have a relatively smaller flow volume and high internal green rate than the first-degree region due to mainly depending on residential zones. Block attributes are hollow, made of brick, and the initial temperature is set to 30 degree Celsius. As for the first-degree region with the most concentrated visitor flow rate and the largest building density, the model uses solid concrete material, and the initial temperature is 40 degrees Celsius. Specific properties of the material, such as reflectivity against solar radiation and thermal absorption, can be further set up depending on the concrete condition. After setting the properties of the block, we need to set the external environment, especially the solar radiation and wind conditions. According to the wind direction, wind velocity and the average temperature in July in Shanghai identified by the above Ecotect software, we set the open surroundings around the area to simulate typical wind environment in July at noon. In terms of solar radiation, the latitude and longitude is set up in CFD where Shanghai lies. Time is set to noon on July 15 , solar incidence coefficient is set to 1.0 , and surface albedo is set to 0.2 . In terms of air flow patterns, the turbulent flow is set to RNG schema and the atmospheric pressure is set to a standard atmospheric pressure $(1.013 \times 105 \mathrm{PA})$. Thus far, the preparatory work of the simulation has been completed.

\section{Analysis on thermal environment simulation results in Shanghai World Expo Park}

Through the simulation in the Air-pak software, we can get the distribution of the temperature, wind speed, air age and solar radiation in July at noon (10:00-14:00) under typical weather conditions before, during and after the World Expo in Shanghai. By analyzing these simulation results comprehensively and comparatively, we can determine the relationship between the Shanghai World Expo Park planning layout and city climate. Through the temperature distribution map (see Figures 15-17), we can clearly see the temperature distribution of the model city 
controlled by the dominant southeast wind. In the circumstances of dominant wind direction in summer afternoon, the area distribution of Shanghai World Expo Park is characterized by multi center city hot area formed mainly by the municipal center, and assisted by the municipal sub

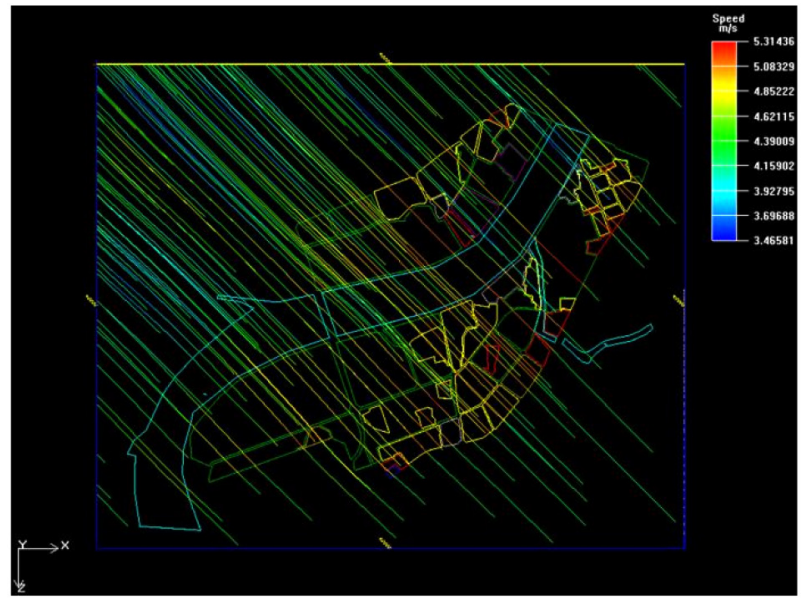

Figure 18. The wind speed flow chart of Expo Park (before the World Expo)

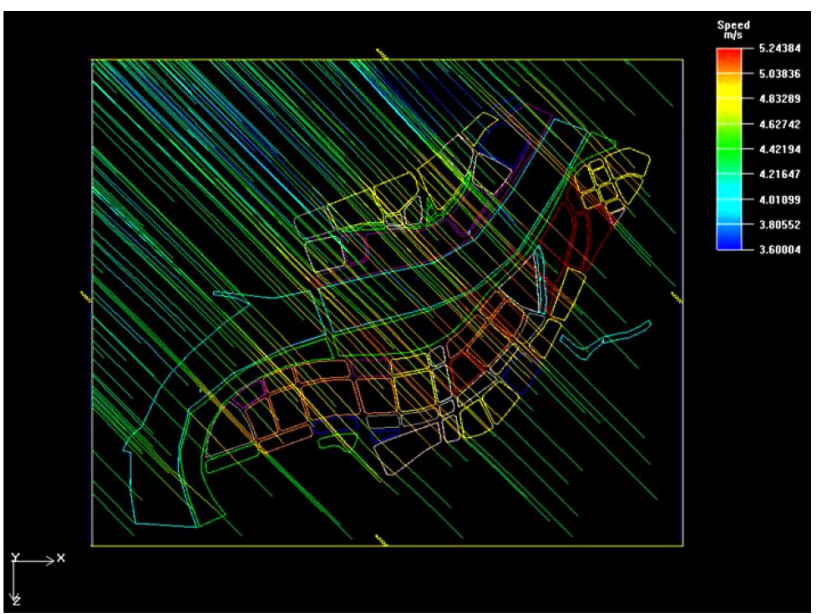

Figure 19. The wind speed flow chart of Expo Park (in the World Expo)

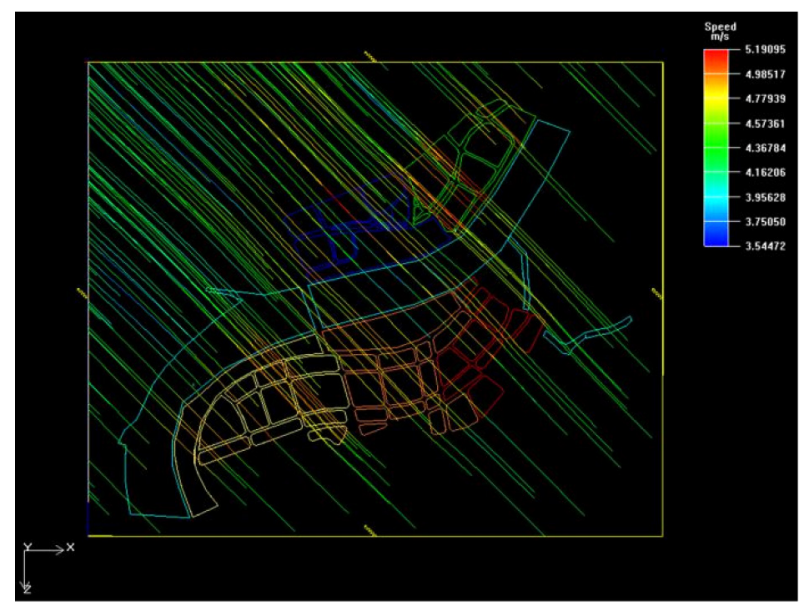

Figure 20. The wind speed flow chart of Expo Park (after the World Expo) center. As the layout of the building changes before, during and after the World Expo, different regions of the city center (red, yellow areas refer to high temperature regions) come into place. In summary, the urban area is higher than the surrounding area in temperature, forming an obvious city "heat-island effect". In the main city zone, the first-degree region is significantly higher than other areas. From the first to fifth area, temperature appears as a decreasing trend (Small, Lu 2006). The Huangpu River formed a cutting force to the city thermal environment, dividing the main city into two pieces. The temperature of riverside plots is relatively low, derived from the dual effects from the evaporation and city corridor ventilation.

Figures 18, 19 and 20 are wind flow diagrams over the urban area. These figures illustrate clearly wind motion direction and speed changes. Due to the influence of the city, the wind direction of monsoon remains largely unchanged when passing over the city, but the wind speed decreases significantly. Wind speed through the city is significantly lower than the upper one. The speed planar graphs (Figures 21-26 refer to Expo interior and upper wind speed graphs respectively) and air age graphs

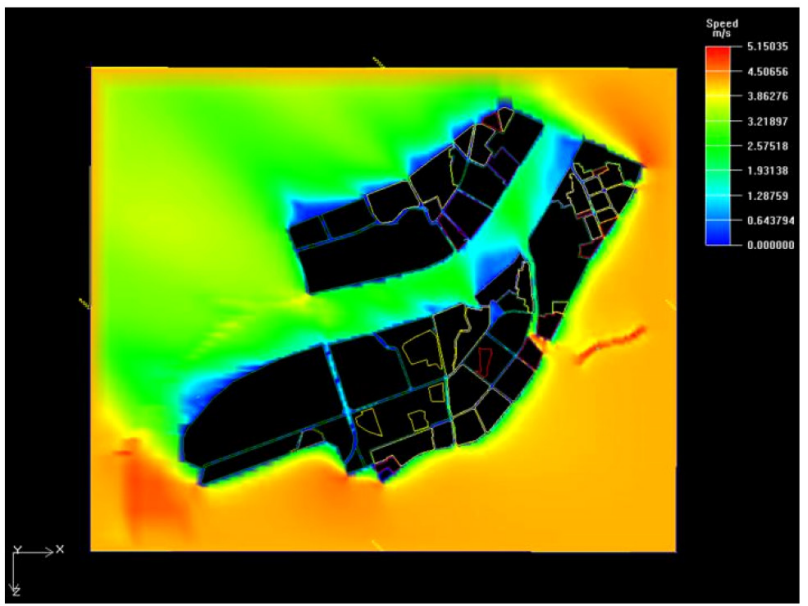

Figure 21. The wind speed in the Expo Park (before the World Expo)

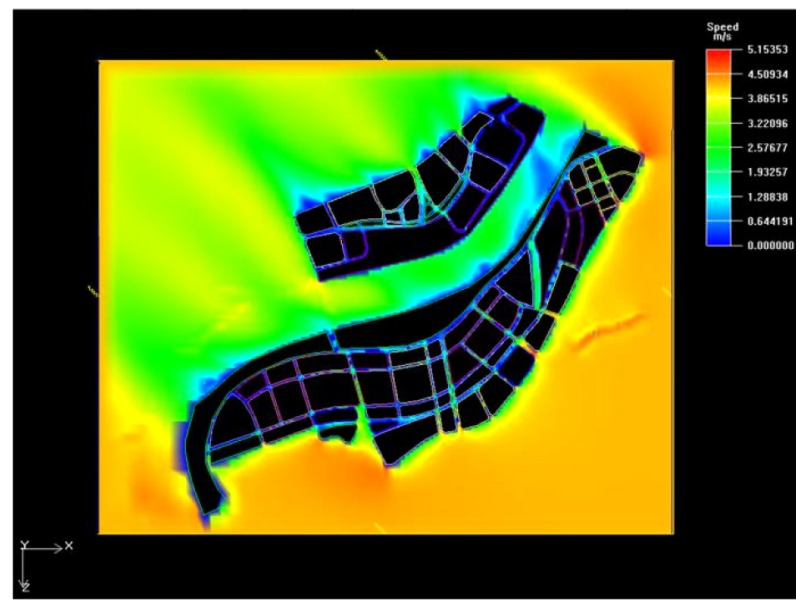

Figure 22. The wind speed in the Expo Park (in the World Expo) 
(Figures 27-32 refer to the main city zone interior and upper air age graphs respectively) demonstrate that wind speed is higher in the suburbs of the city and the air age index is relatively shorter. Therefore, the retention time of

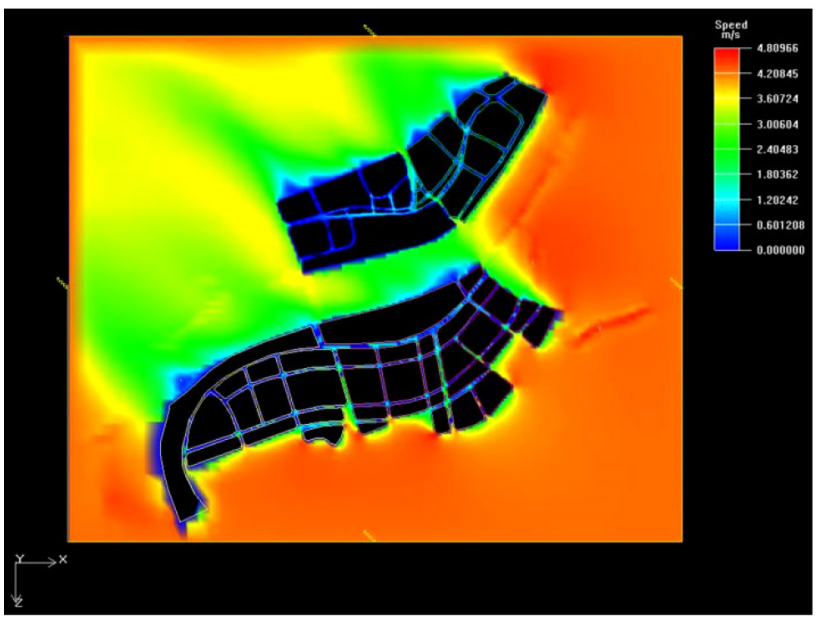

Figure 23. The wind speed in the Expo Park (after the World Expo)

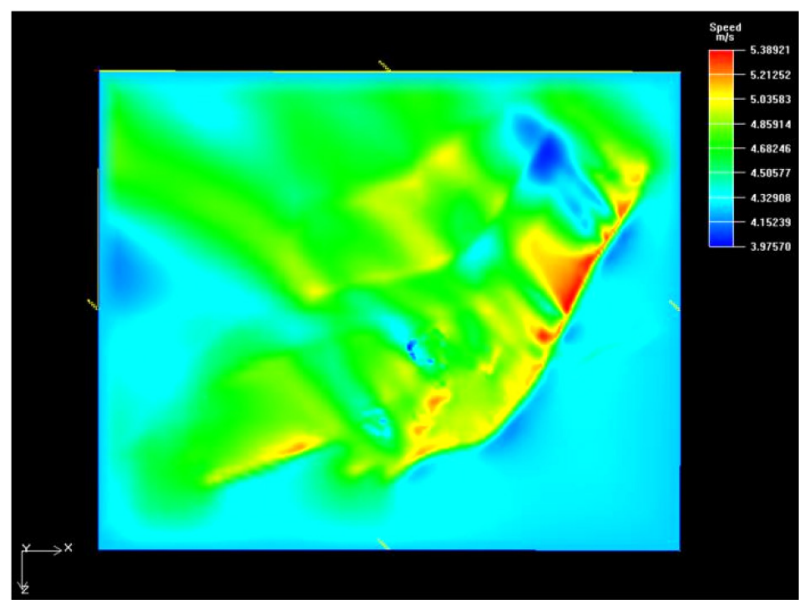

Figure 24. Wind speed above the Expo Park (before the World Expo)

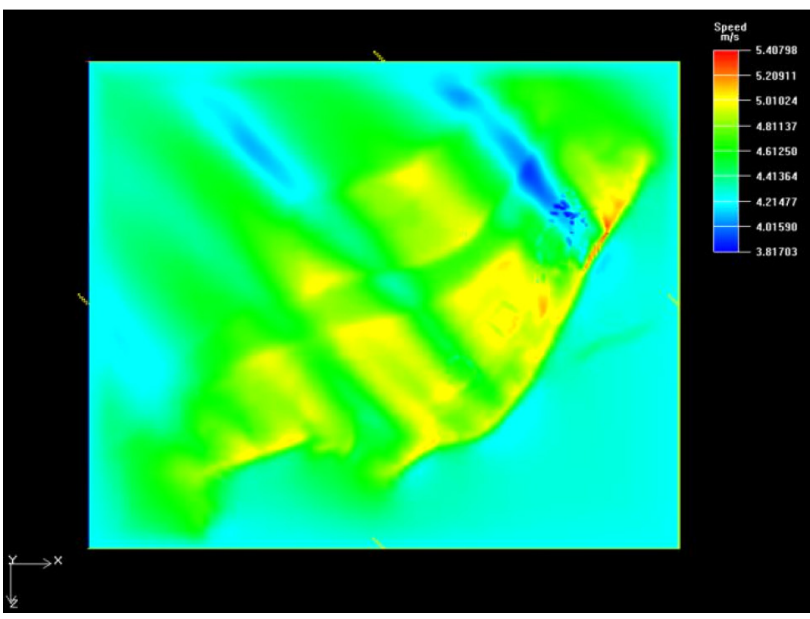

Figure 25. Wind speed above the Expo Park (in the World Expo) wind around the urban residence is short. When passing the main city zone, the speed decreases significantly due to occlusion from the buildings in the city. The air age index is relatively longer, with an obvious wind shadow zone

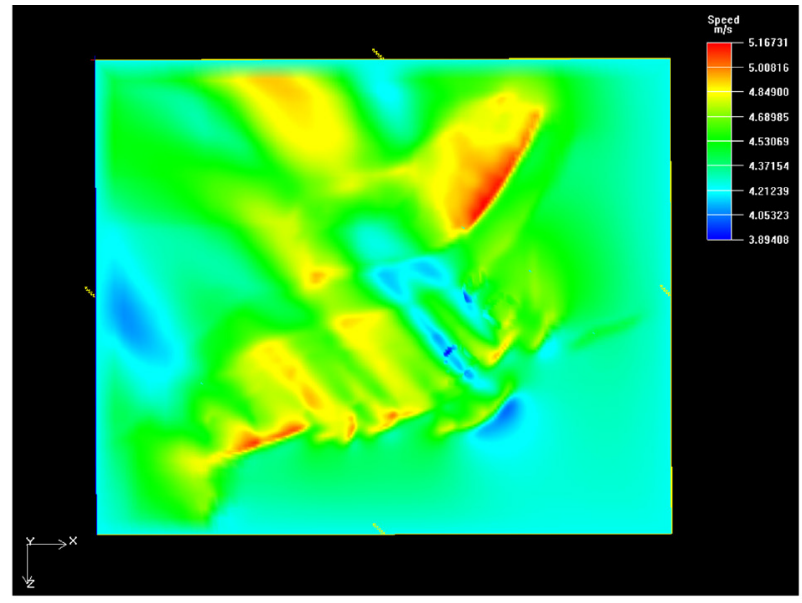

Figure 26. Wind speed above the Expo Park (after the World Expo)

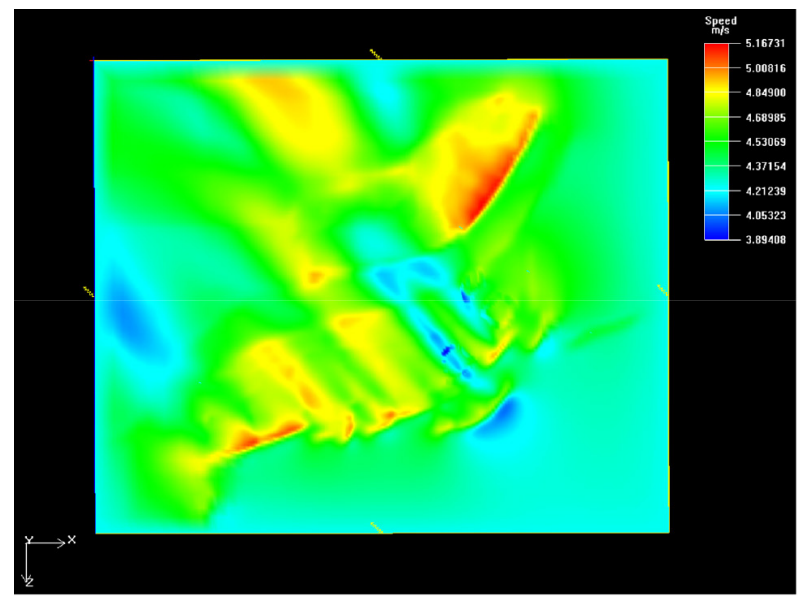

Figure 27. Air age chart in the Expo Park (before the World Expo)

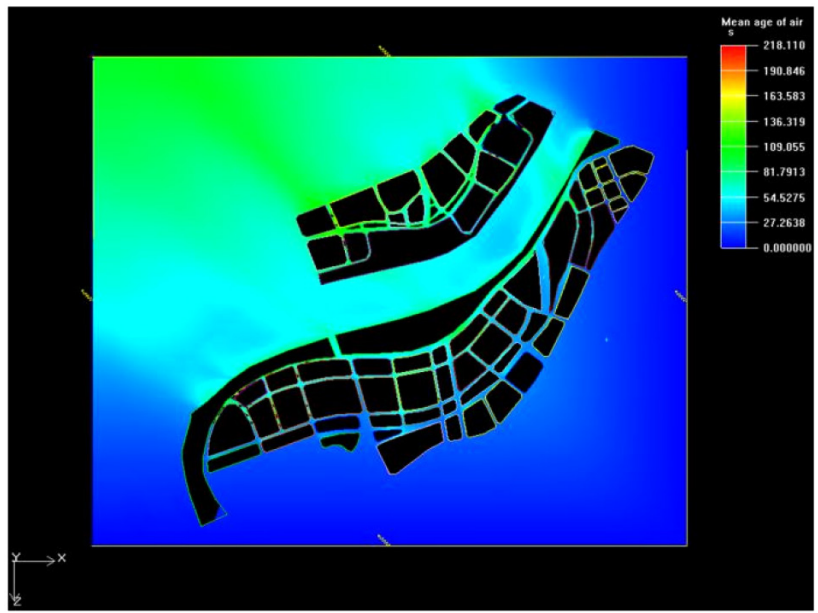

Figure 28. Air age chart in the Expo Park (in the World Expo) 
in the leeward side of the city. Some street air age is relatively shorter with the same wind direction. In addition, through the longitudinal comparison from Figures 21-26 at different heights, we also discover that the upper area of

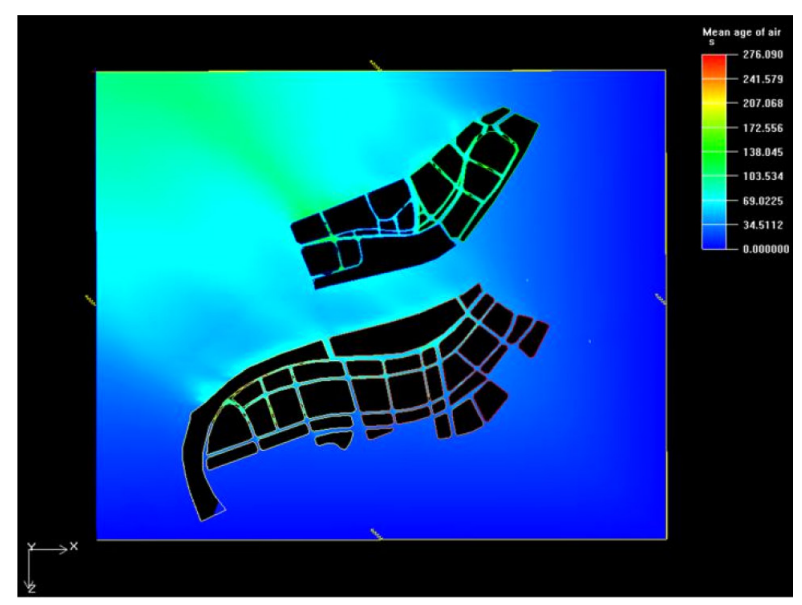

Figure 29. Air age chart in the Expo Park (after the World Expo)

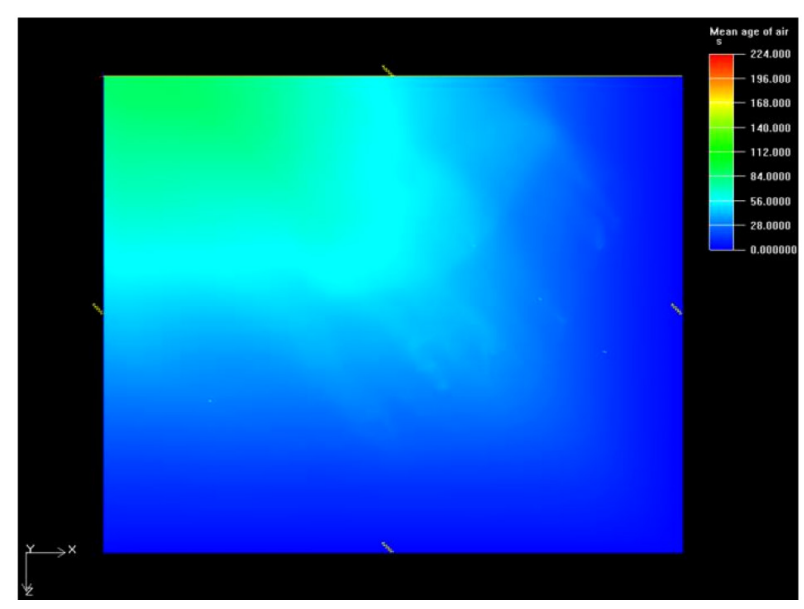

Figure 30. Air age chart above the Expo Park (before the World Expo)

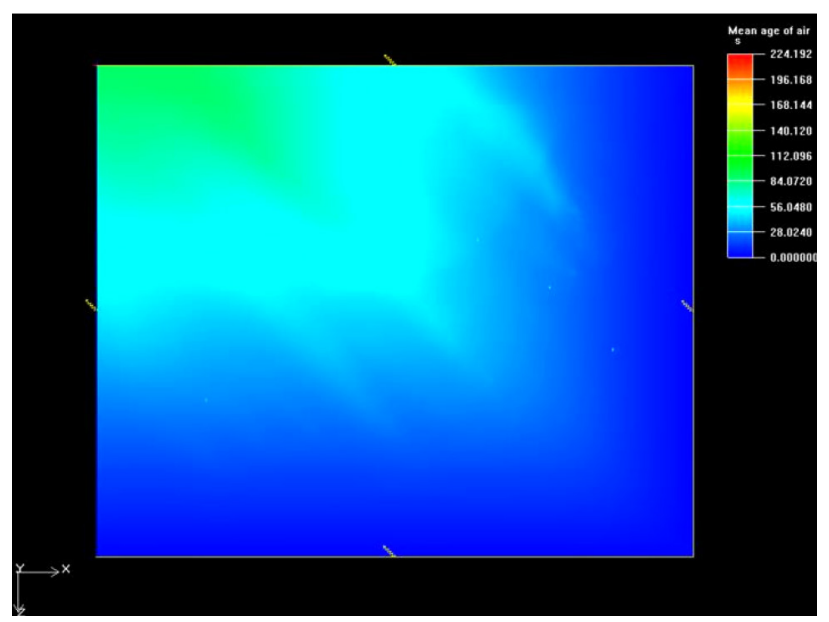

Figure 31. Air age chart above the Expo Park (in the World Expo) the Expo Park is not sheltered from the below buildings, but it is affected by the city below. The wind speed over the city cuts down while the air age increases. With the height increasing, such trends become smaller and smaller. The simulation experiment suggest that the urban "heat-island effect" is the dual result (Weng et al. 2004) of the heat and poor ventilation generated by urban underlying surface changes. With the improvement of ventilation, the whole temperature distribution of the urban heat-island takes on a decreasing tendency from bottom to top. With the comparison measured by relevant data, the CFD simulation results are in accordance with the actual situation. The Expo Center area, China Pavilion and Expo Axis (including commercial and financial center, the distribution activities land) generate urban "heat-island effect" due to the city's underlying surface changes, high building density, large population density and the solar radiation forming bad air flow. Huangpu District, Yangtze River, wetlands, parks and large green surrounding areas alleviate the effect of "heat-island effect", due to the water and plants with relatively low temperature, adjusting the surrounding microclimate.

\section{Conclusions}

Digital simulation is a rapid, efficient and economical research method. Compared with traditional methods, it not only reduces manpower and material resources, but can also complete experiments that could not be completed by the traditional methods. It allows for filling in the blanks of the previous research method. In this study, we combine the Ecotect software and CFD software, simulating the thermal environment of the city in the Shanghai World Expo in July at noon under typical working conditions, in order to obtain a deeper understanding of the urban "heat-island effect" distribution causes and a series of climatic factors closely related to urban heat environment. Such factors include wind speed, temperature, radiation temperature and atmospheric pressure. In turn, we can

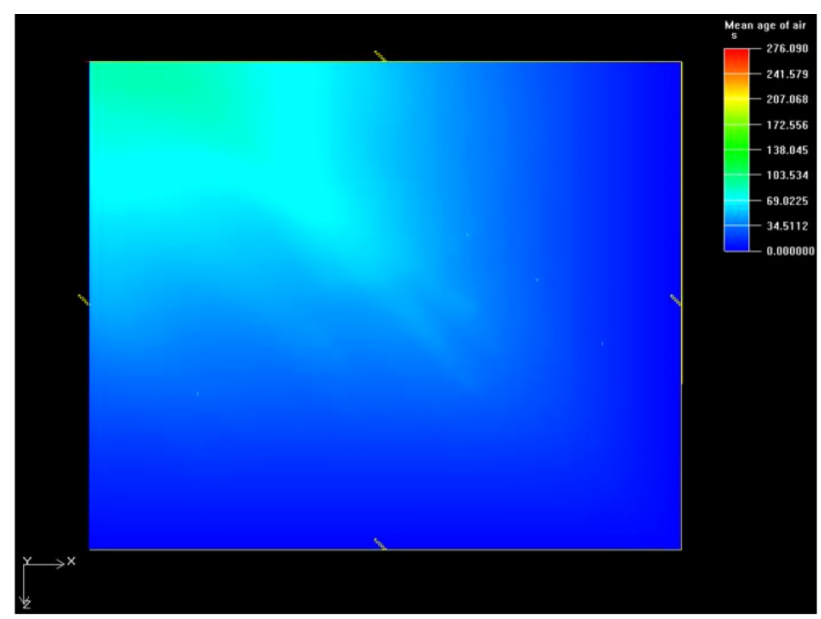

Figure 32. Air age chart above the Expo Park (after the World Expo) 
implement these research means to improve the urban the heat-island effect, and provide a better solution to enhance thermal comfort. With broad application, these research methods can also be introduced in future urban planning, formulate design guidelines for corresponding urban climate environments according to different geographical and climatic characteristics of cities (Powell et al. 2007). It can also put forward suggestions for the urban space layout, ventilation corridors, and green space layout, and provide references for city planning and management department. It can not only improve the urban thermal environment, creating a "livable city", but also it is significant in achieving the strategic objectives of China's "building a resource-saving and environment-friendly society" and "low carbon city".

According to the characteristics of the Shanghai World Expo Park development, energy planning processes and technical factors are formulated. According to the different functions of the garden, energy planning is drawn up, as well as a series of linkage mechanisms and policies. In the future development of the World Expo Park, the main focus will be the implementation of an energy center system and pipe network project, massive natural gas combined with a cooling, heating and electricity energy center for demonstrating building methods. Energy planning is integrated into the overall planning of the expo to continue and diffuse the follow-up effect of the Shanghai World Expo in the social, economic, environmental aspects (Fei, Marvin 2007). At present, the energy planning has not been included in the national laws and regulations. Energy planning standards and guidelines should be published as soon as possible. Different energy planning factors are drafted according to different regions, combined with other planning to achieve effective energy systems.

\section{Acknowledgements}

This work was financially supported by the national invention patents of ZL 201310080487.4 and ZL 20131 0080484.0.

\section{References}

Basara, J. B.; Basara, H. G.; Illston, B. G.; Crawford, K. C. 2010. The impact of the urban heat island during an intense heat wave in Oklahoma City, Advances in Meteorology 2010: 230365. 10 p. https://doi.org/10.1155/2010/230365

Bohnenstengel, S. I.; Evans, S.; Clark, P. A.; Belcher, S. E. 2011. Simulations of the London urban heat island, Quarterly Journal of the Royal Meteorological Society 137(659): 1625-1640. https://doi.org/10.1002/qj.855

Callahan, W. A. 2012. Shanghai's alternative futures: the World Expo, citizen intellectuals, and China's new civil society, China Information 26(2): 251-273.

https://doi.org/10.1177/0920203X12442889

Emmanuel, R.; Krüger, E. 2012. Urban heat island and its impact on climate change resilience in a shrinking city: the case of Glasgow, UK, Building and Environment 53: 137-149.

https://doi.org/10.1016/j.buildenv.2012.01.020
Fei, Y.; Marvin, E. B. 2007. Comparison of impervious surface area and normalized difference vegetation index as indicators of surface urban heat island effects in Landsat imagery, Remote Sensing of Environment 106(3): 375-386. https://doi.org/10.1016/j.rse.2006.09.003

Goward, S. N. 2004. Thermal behavior of urban landscapes and the urban heat island, Physical Geography 2(1): 19-23.

Hao, N.; Valks, P.; Loyola, F.; Cheng, D. Y.; Zimmer, W. 2011. Space-based measurements of air quality during the World Expo 2010 in Shanghai, Environmental Research Letters 6(4): 044004. https://doi.org/10.1088/1748-9326/6/4/044004

Lamberti, L.; Noci, G.; Guo, J.; Zhu, S. 2011. Mega-events as drivers of community participation in developing countries: the case of Shanghai World Expo, Tourism Management 32(6): 1474-1483. https://doi.org/10.1016/j.tourman.2010.12.008

Li, J.; Song, C.; Cao, L.; Zhu, F.; Meng, X.; Wu, J. 2011. Impacts of landscape structure on surface urban heat islands: a case study of Shanghai, China, Remote Sensing of Environment 115(12): 3249-3263. https://doi.org/10.1016/j.rse.2011.07.008

Li, Y. L. X. 2012. Analysis of the planning of neighborhood communication space in the livable community, Applied Mechanics and Materials 174: 3018-3022. https://doi.org/10.4028/ www.scientific.net/AMM.174-177.3018

Li, Y. L. X. 2016. The green ecological environment in Shanghai Free Trade Area, Nature Environment and Pollution Technology 15(2): 755-760.

Nichol, J.; Wong, M. S. 2005. Modeling urban environmental quality in a tropical city, Landscape and Urban Planning 73(1): 49-58. https://doi.org/10.1016/j.landurbplan.2004.08.004

Oleson, K. W.; Bonan, G. B.; Feddema, J.; Jackson, T. 2011. An examination of urban heat island characteristics in a global climate model, International Journal of Climatology 31(12): 1848-1865. https://doi.org/10.1002/joc.2201

Powell, R. L.; Roberts, D. A.; Dennison, P. E.; Hess, L. L. 2007. Sub-pixel mapping of urban land cover using multiple endmember spectral mixture analysis: Manaus, Brazil, Remote Sensing of Environment 106(2): 253-267. https://doi.org/10.1016/j.rse.2006.09.005

Prakash, A.; Gupta, R. P.; Saraf, A. K. 2006. A Landsat TM based comparative study of surface and subsurface fires in the Jharia coalfield, India, International Journal of Remote Sensing 18(11): 2463-2469. https://doi.org/10.1080/014311697217738

Scheuer, C.; Keoleian, G. A.; Reppe, P. 2003. Life cycle energy and environmental performance of a new university building: modeling challenges and design implications, Energy and Buildings 35(10): 1049-1064.

Small, Ch.; Lu, J. W. T. 2006. Estimation and vicarious validation of urban vegetation abundance by spectral mixture analysis, Remote Sensing of Environment 100(4): 441-456. https://doi.org/10.1016/j.rse.2005.10.023

Stathopoulou, M.; Cartalis, C. 2007. Daytime urban heat islands from Landsat ETM+ and Corine land cover data: an application to major cities in Greece, Solar Energy 81(3): 358-368. https://doi.org/10.1016/j.solener.2006.06.014

Steeneveld, G. J.; Koopmans, S.; Heusinkveld, B. G.; van Hove, L. W. A.; Holtslag, A. A. M. 2011. Quantifying urban heat island effects and human comfort for cities of variable size and urban morphology in the Netherlands, Journal of Geophysical Research: Atmospheres (1984-2012), 116(D20). https://doi.org/10.1029/2011JD015988

Tan, J.; Zheng, Y.; Tang, X.; Guo, Ch.; Li, L.; Song, G.; Zhen, X.; Yuan, D.; Kalkstein, A. J.; Li, F.; Chen, H. 2010. The urban heat island and its impact on heat waves and human health in Shanghai, International Journal of Biometeorology 54(1): 75-84. https://doi.org/10.1007/s00484-009-0256-x 
Tomlinson, C. J.; Chapman, L.; Thornes, J. E.; Baker, Ch. J. 2011. Including the urban heat island in spatial heat health risk assessment strategies: a case study for Birmingham, UK, International Journal of Health Geographics 10(1): 42. https://doi.org/10.1186/1476-072X-10-42

Weng, Q.; Lu, D. S.; Jacquel, Y. S. 2004. Estimation of land surface temperature-vegetation abundance relationship for urban heat island studies, Remote Sensing of Environment (89): 467-483. https://doi.org/10.1016/j.rse.2003.11.005

Xu, J.; Wei, Q.; Huang, X.; Zhu, X.; Li, G. 2010. Evaluation of human thermal comfort near urban waterbody during summer, Building and Environment 45(4): 1072-1080.

https://doi.org/10.1016/j.buildenv.2009.10.025
Yang, L. 2014. Green building design: wind environment of building. Shanghai: Tongji University Press.

Yang, L. 2016. Green building design: building energy efficiency. Shanghai: Tongji University Press.

Yang, L.; He, B. J.; Miao, Y. 2014. Application research of ECOTECT in Residential Estate Planning, Energy and Buildings 72: P195-202.

https://doi.org/10.1016/j.enbuild.2013.12.040

Zhang, X. 2013. Going green: Initiatives and technologies in Shanghai World Expo, Renewable and Sustainable Energy Reviews 25: 78-88.

https://doi.org/10.1016/j.rser.2013.04.011 